\title{
HISTOARCHITECTURE OF THE THYROID GLAND IN PIGLETS WITH HYPOTROPHY AND AFTER THE COURSE OF MEDICAL CORRECTION
}

\author{
G.Zh. Bilzhanova \\ Orenburg State Agrarian University \\ Orenburg, 460014, Russian Federation \\ bilzhanovagulnara@mail.ru
}

\begin{abstract}
Antenatal malnutrition is a condition characterized by both a weight loss in animals and a change in the morphofunctional characteristics of the internal organs, particularly the incompleteness of the thyroid gland structure that will have a direct impact on the further growth and development of animals. Therefore, the aim of the research was to establish the patterns of histostructure of the thyroid gland inhypotrophic piglets and piglets after prenatal correction of hypotrophy considering their age. The study was performed on piglets of the large white breed. The study material was the thyroid gland of hypotrophic piglets and piglets after prenatal correction with Sedimin at 1, 5, 15 and 30 days of age. The main methods of study: histological, morphometric and statistical data processing.

According to the research results, a thickening of the connective tissue capsule of the thyroid gland in newborns and five-day-old hypotrophic piglets was established in relation to fifteen and thirty-day-old ones. The average diameter of the follicle is at a relatively equal level during all periods of the study, the colloid acquired a "foamy" appearance on the fifth and fifteenth day. The form of thyrocytes and their nuclei changed with age from flattened to cubic.

Cell-tissue composition of the thyroid gland of piglets after prenatal correction of malnutrition is functionally active. On the first and fifth days the capsule of the organ was thinned, by the end of the study its thickness increased markedly. The diameter of the follicles of the thyroid gland decreased from the neonatal period to the thirtieth day. Throughout the experiment, the structure of the colloid changed in the follicle lumen from homogeneous consistency to "frothy" by the end of the experiment. At the beginning of the experiment, both flattened and cubic-shape epithelial cells were observed in the parenchyma of the thyroid gland, by the thirtieth day it was stably cubic. The nuclei of thyrocytes are mostly spherical and hypochromic.

In conclusion, it is worth noting that in hypotrophic piglets in the neonatal period and in the five-day age, the incompleteness of the structure of the thyroid gland was observed, the further morphological reorganization reached by the thirtieth day. The medication "Sedimin" had a positive effect on the body of pigs, reducing the degree of development of malnutrition and contributing to the adequate organoand histogenesis, including the thyroid gland.
\end{abstract}

Key words: thyroid gland, follicle, colloid, thyrocyte, Sedimin, large white breed, hypotrophic piglets, prevention of hypotrophy

\section{INTRODUCTION}

Hypotrophy is a disease of newborn piglets, characterized by underdevelopment, low live weight and low resistance to adverse environmental factors. The etiology of antenatal malnutrition is associated with a violation of the norms of feeding pregnant sows, the occurrence of metabolic disturbances in them causes toxicosis of gestation and results in fetal toxicosis and hypoxia, metabolic disorders in fetus, weakening of the 
differentiation of the tissues and organs of the fetus, which all in all lead to morphological and functional immaturity of piglets $[1,2]$. Antenatal hypotrophy is characterized by a lag in the growth of individual organs, the underdevelopment of internal organs can manifest as a decrease in their absolute mass, and anstructural inferiority of their parenchyma (cell immaturity, insufficient differentiation), which leads to a decrease in reactivity, metabolic pathologies and toxicosis [3-5]. One of the important organs responsible for the growth and development of the fetus is thyroid gland, a cell-tissue composition of which is directly expressed in its functional ability [4, 6-8]. Prenatal prevention of malnutrition is timely formation of tissues and organs, with their further inclusion in metabolic processes, such organs include the thyroid gland, whose thyroid hormones directly affect metabolism [9-11].

The aim of the study is to establish the patterns of histostructures of the thyroid gland in hypotrophic piglets after prenatal correction of hypotrophy considering age.

\section{MATERIALS AND METHODS}

Scientific research was carried out on large white breed piglets on the basis of APC "Pokrovsky" of the Orenburg region and the Department of morphology, physiology and pathology of Orenburg State Agrarian University. Two groups of animals were formed: the first is the control of malnutrition, and the second is the piglets after the prenatal prevention of malnutrition with Sedimin. The object of the study was the thyroid gland from piglets at the age of 1, 5, 15 and 30 days. Histological, morphometric and statistical research methods were used.

\section{RESULTS AND DISCUSSION}

The histoarchitecture of the thyroid gland of day-old hypotrophic piglets is relatively homogeneous (Fig. 1). The thickness of the connective tissue organ capsule was $42.03 \pm 12.60$ microns. In the parenchyma of the gland, spherical follicles were viewed, with a diameter $(\varnothing$ - diameter $)-5.98 \pm 0.48 \mu \mathrm{m}$. In the follicle lumen colloid is pink, layered, homogeneous consistency. Locally, resorptive vacuoles were observed in the colloid. Thyrocytes (height $-0.70 \pm 0.06 \mu \mathrm{m}$ ) are flattened, the structure of the cytoplasm is not visualized, the hyperchromic nuclei are flat, the nucleoli are not visualized $(\varnothing-0.38 \pm 0.04 \mu \mathrm{m}, \mathrm{NPR}=0.54)$. The vascular bed is filled with blood.

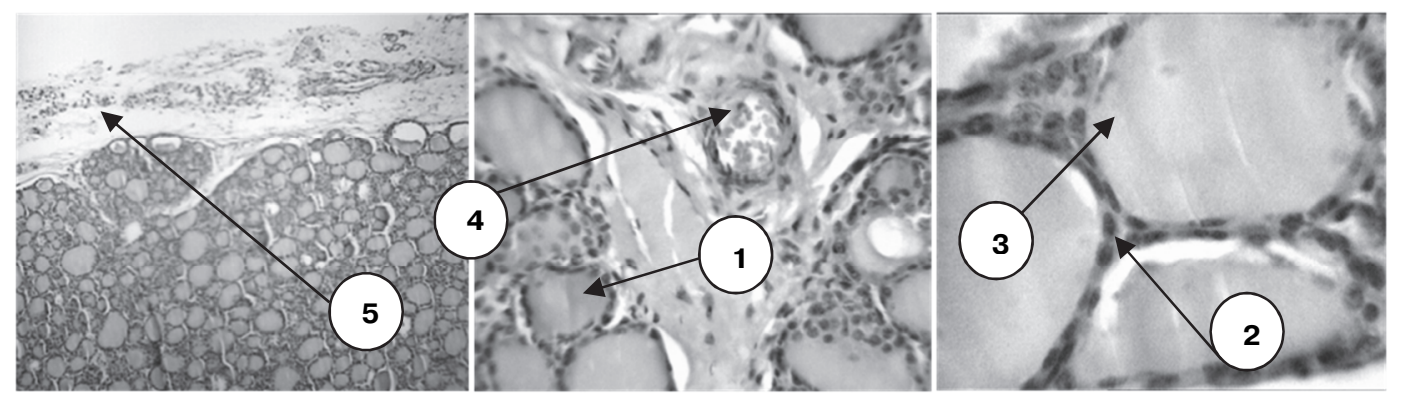

Fig. 1. Thyroid gland of day-old piglets of the first experimental group:

A $-\times 150$; B $-\times 600$; C $-\times 1500$; Mayer's hematoxylin and eosin:

1 - follicles; 2 - thyrocytes; 3 - colloid; 4 - arteriole; 5 - capsule 
Histoarchitecture of the thyroid gland of five-day-old hypotrophic piglets is isomorphic. The thickness of the surrounding parenchyma of the thyroid gland capsule is $48.33 \pm 0.837$ microns. In the center of the organ there are spherical shape and smaller in size follicles $(\varnothing-6.16 \pm 0.76 \mu \mathrm{m})$, increasing in diameter and acquiring an ovoid shape to the periphery of the organ. Folliculogenesis processes are observed in the central part of the parenchyma of the gland. In the cavities of the follicles, the colloidal mass is red-pink, with the presence of significant resorption zones. Thyrocytes has a flattened shape (height $-0.64 \pm 0.06 \mu \mathrm{m})$. The nuclei of thyrocytes are flat $(\varnothing-0.34 \pm 0.04 \mu \mathrm{m}$, NPR $=0.55)$, hyperchromic, and the nucleoli are not visualized. The lumens of the blood vessels of the microvascular bed (MVB) are weakly filled or empty (Fig. 2).
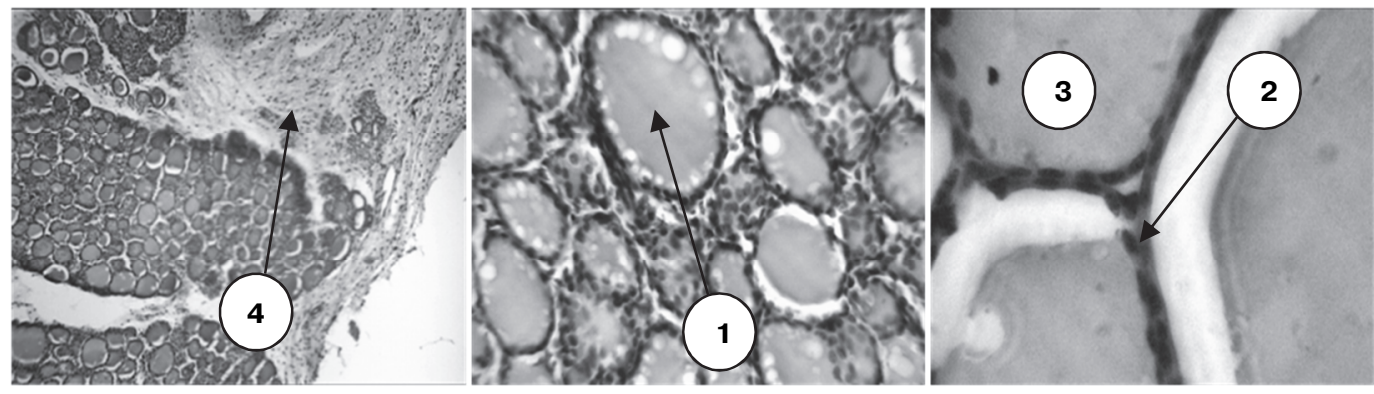

Fig. 2. Thyroid gland of 5-day-old piglets of the first experimental group:

A $-\times 150$; B $-\times 600$; C $-\times 1500$; Mayer's hematoxylin and eosin:

1 - follicles; 2 - thyrocytes; 3 - colloid; 4 - capsule

The connective tissue capsule of the thyroid gland of fifteen-day-old hypotrophic piglets is prominent throughout $-27.0 \pm 5.67 \mu \mathrm{m}$, the organ parenchyma is distinctly divided into lobules by trabeculae (Figure 3). Follicles of both spherical and ovoid shape (Ø $6.88 \pm 0.58 \mu \mathrm{m})$ are encountered. The colloid filling the follicles has a color from pale pink to pink, "foamy" consistency, with resorption zones. Half-empty and empty follicles on the periphery of the organ are visualized. The follicular epithelium is from flat to cubic form (height $-0.98 \pm 0.06 \mu \mathrm{m}$ ) with a weakly-oxophilic cytoplasm. Spherical nuclei of thyrocytesare hypochromic, visualization of the nucleoli is noted $(\varnothing-0.58 \pm$ $\pm 0.056, \mathrm{NPR}=0.59$ ). Intense blood filling is observed in microvascular bed.

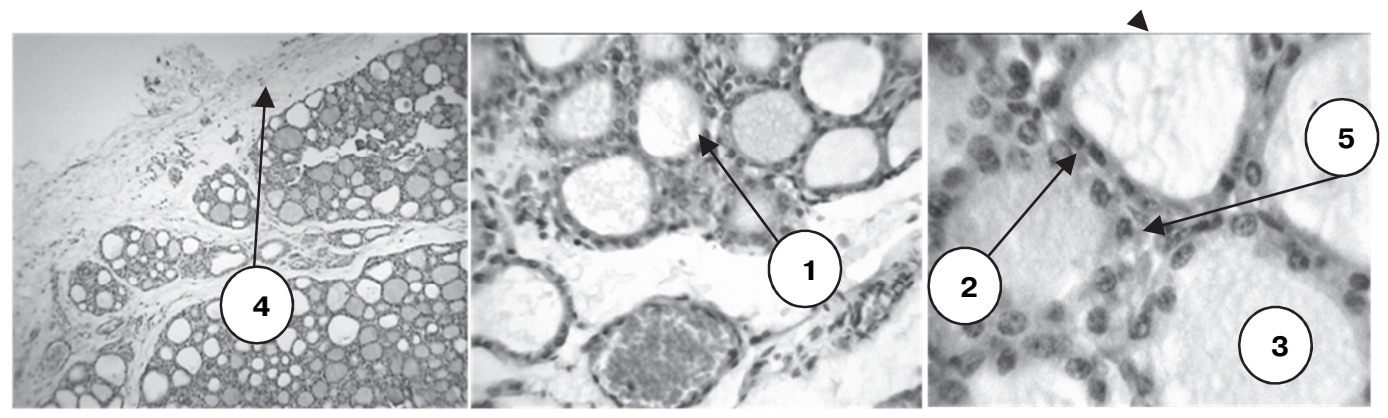

Fig. 3. Thyroid gland of 15-day-old piglets of the first experimental group:

A $-\times 150$; B $-\times 600$; C $-\times 1500$; Mayer's hematoxylin and eosin:

1 - follicles; 2 - thyrocytes; 3 - colloid; 4 - capsule; 5 - capillary 
On the thirtieth day a moderately developed connective tissue capsule is observed in the histostructure of the thyroid gland - $40.95 \pm 14.94$ microns. The shape and size of the follicles are variable over the entire area of the specimen, most of them are spherical and ovoid shape $(\varnothing-6.02 \pm 0.64 \mu \mathrm{m})$, with rarely observed triangular shaped structures. The colloidal component is from pale pink to red-pink in color, the consistency is homogeneous, lamination is noted. In low prismatic thyrocytes (height $-1.20 \pm$ $\pm 0.08 \mu \mathrm{m}$ ), a weakly oxidizing cytoplasm is observed, with the presence of vacuolization. The nuclei of the thyrocytes has a spherical shape, the color is hypochromic, the nucleoli are visible $(\varnothing-0.76 \pm 0.042 \mu \mathrm{m}, \mathrm{NPR}=0.62)$. The intensive metabolism is observed in the vascular bed (Fig. 4).

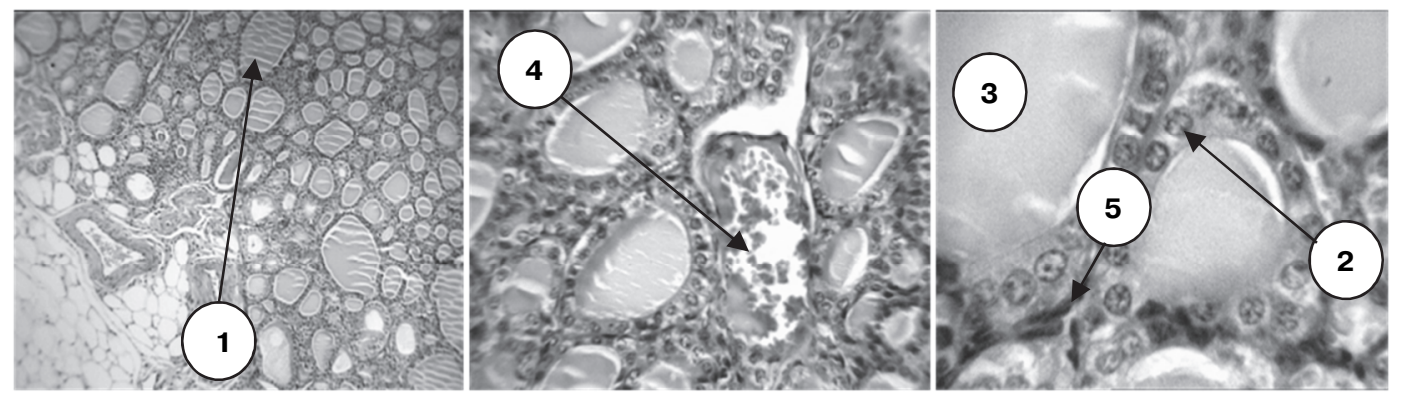

Fig. 4. Thyroid gland of 30 -day-old piglets of the first experimental group:

A $-\times 150$; B $-\times 600$; C $-\times 1500$; Mayer's hematoxylin and eosin: 1 - follicles; 2 - thyrocytes; 3 - colloid; 4 - venule; 5 - capillary

Histoarchitecture of the thyroid gland of day-old piglets after prenatal correction with complex medication "Sedimin" is heteromorphic (Fig. 5). The connective tissue capsule is changed throughout the organ, either thickening or gradually becoming thinner, an average of $22.86 \pm 4.77$, whose trabeculae divide the parenchyma into lobules. The follicles are variable, spherical in shape and small in size $(\varnothing-7.56 \pm 0.42 \mu \mathrm{m})$, the formation of new follicles is continued. The colloid is oxyphilic, homogeneous, layered. Thyrocytes range from flat to cubic cells (height $-0.92 \pm 0.076 \mu \mathrm{m})$, moderately colored, hypochromic, spherical $(\varnothing-0.64 \pm 0.04 \mu \mathrm{m}, \mathrm{NPR}=0.69)$, locally flattened, nucleoli are well visualized. MVB is moderately filled with blood.

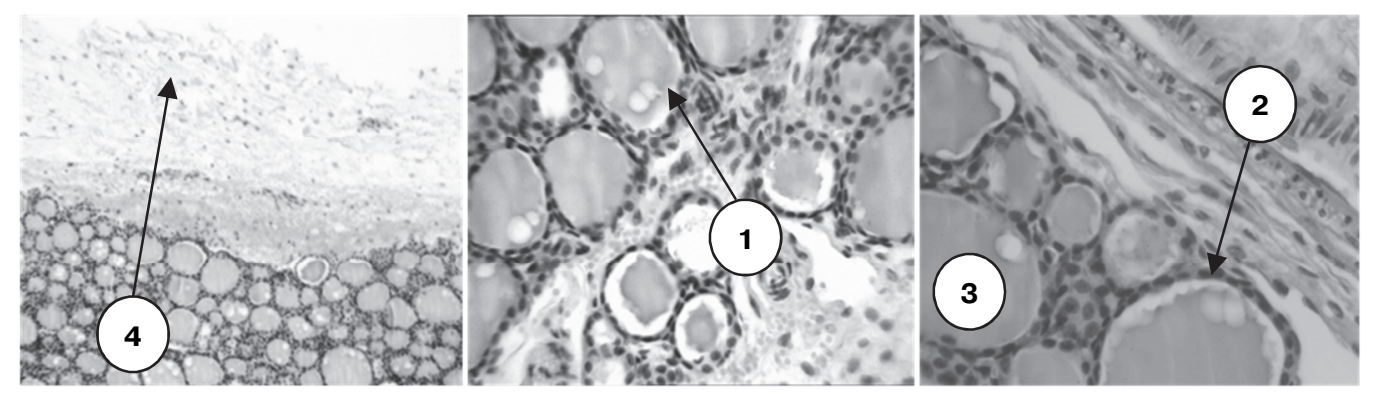

Fig. 5. Thyroid gland daily piglets of the second experimental group:

A $-\times 150$; B $-\times 600$; C $-\times 1500$; Mayer's hematoxylin and eosin:

1 - follicles; 2 - thyrocytes; 3 - colloid; 4 - capsule 
The micromorphology of the thyroid gland of piglets of the second group on the fifth day is heterogeneous (Fig. 6). The thickness of the connective tissue capsule is $10.53 \pm 5.40$ microns. The follicles predominate in spherical shape, smaller sizes in the center and large on the periphery $(\varnothing-6.94 \pm 0.94$ microns $)$. In addition, follicles of polygonal form, including stellate, are observed. The follicle cavities are filled with pink, homogeneous, layered colloid. Resorption sites along the periphery of the follicle cavity are observed. Proliferation zones of the follicular epithelium indicate offolliculogenesis. Thyrocytes are from flat to cubic form (height $-0.78 \pm 0.064$ ), cytoplasm is weakly oxyphilous, nucleus of thyrocytes has from flattened to spherical configuration $(\varnothing-$ $0.50 \pm 0.048 \mu \mathrm{m}, \mathrm{NPR}=0.64$ ), hyperchromic, nucleoli are not visible. The vascular bed is moderately filled with blood.

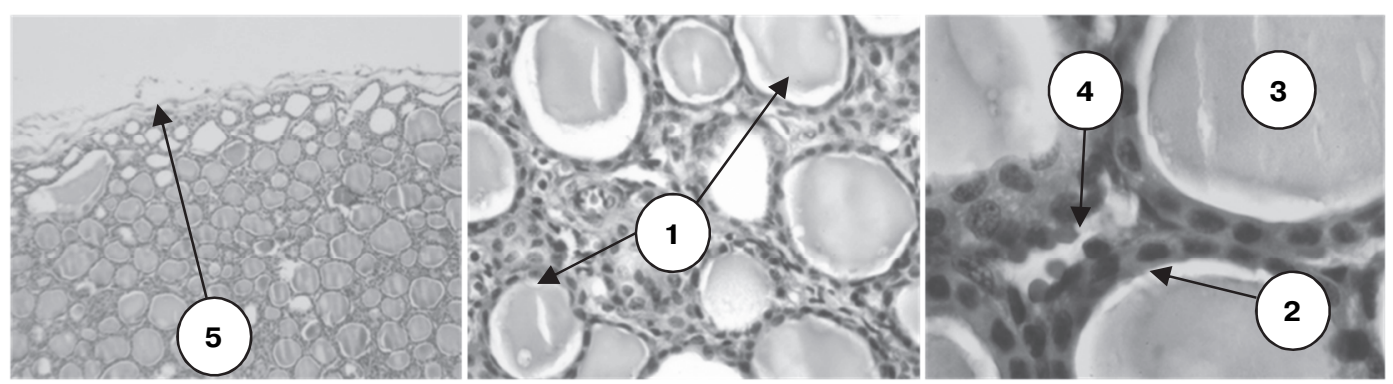

Fig. 6. Thyroid gland of 5-day pigs of the second experimental group:

A $-\times 150$; B $-\times 600$; C $-\times 1500$; Mayer's hematoxylin and eosin:

1 - follicles; 2 - thyrocytes; 3 - colloid; 4 - capillary; 5 - capsule

On the fifteenth day, the thickness of the capsule is $46.53 \pm 7.65$ microns. The shape of the follicle is characterized by variability $(\varnothing-7.02 \pm 0.42 \mu \mathrm{m})$, in the center of the thyroid parenchyma tissue clusters are small and spherical, large in size and ovoid shape at the periphery. Colloid is pink, granular consistency, with resorption zones. Processes of folliculogenesis are observed. Thyrocytes (height $-0.70 \pm 0.04 \mu \mathrm{m}$ ) are variable in shape from flat to low prismatic, cytoplasm is oxyphilic, hypochromic nuclei of spherical thyrocytes $(\varnothing-0.50 \pm 0.038 \mu \mathrm{m}, \mathrm{NPR}=0.72)$, nucleoli are visualized. The vascular bedis characterized by intense metabolic processes in the thyrohematic barrier (Fig. 7).

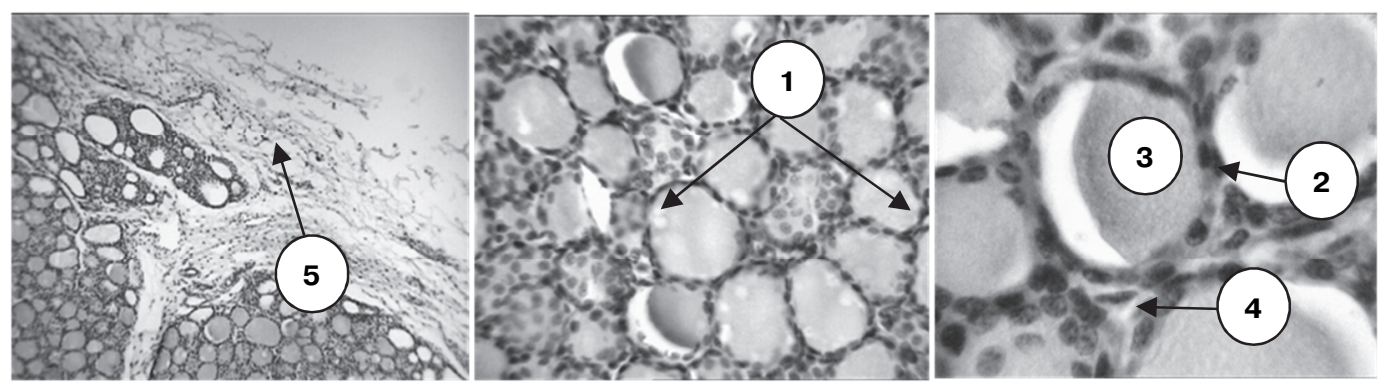

Fig. 7. Thyroid gland of 15 -day pigs of the second experimental group:

A $-\times 150$; B $-\times 600$; C $-\times 1500$; Mayer's hematoxylin and eosin:

1 - follicles; 2 - thyrocytes; 3 - colloid; 4 - capillary; 5 - capsule 
The histostructure of the thyroid gland of piglets on the thirtieth day is characterized by the presence of a moderately developed capsule $(10.58 \pm 11.25 \mu \mathrm{m})$. Follicles $(\varnothing-$ $5.42 \pm 0.38 \mu \mathrm{m})$ are spherical in shape and smaller in the center, oval and large at the periphery of the parenchyma of the organ. The colloid is pink, "foamy", layered, with the presence of resorptive vacuoles. Thyrocytes (height $-0.90 \pm 0.10 \mu \mathrm{m}$ ) are cubic inshape, cytoplasm is weakly acidic, the nucleus of thyrocytes $(\varnothing-0.66 \pm 0.044 \mu \mathrm{m}$, $\mathrm{JAPO}=0.73$ ) are spherical, hypochromic, nucleoli are visualized. The MCBis intensively filled with blood (Fig. 8).

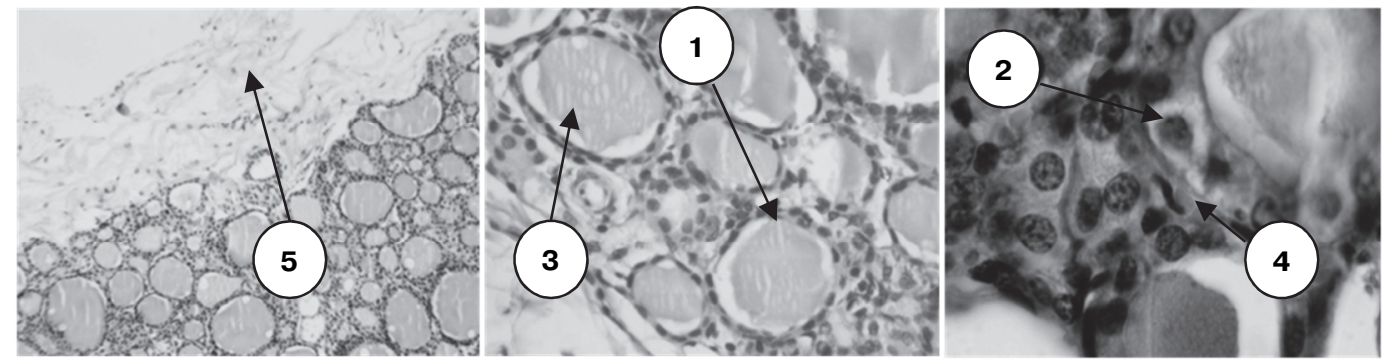

Fig. 8. Thyroid gland of 30-day pigs of the second experimental group:

A $-\times 150$; B $-\times 600$; C $-\times 1500$; Mayer's hematoxylin and eosin:

1 - follicles; 2 - thyrocytes; 3 - colloid; 4 - capillary; 5 - capsule

\section{CONCLUSIONS}

Thus, the analysis showed that on the first and fifth days the hypotrophic piglets thyroid gland had a thickening of the capsule, a decrease in the diameter of the follicles and thyrocytes and the flattening of their nuclei in comparisonwith the piglets after the use of the Sedimin complex medication. By the fifteenth and thirtieth days, the micromorphology of the thyroid gland of piglets of both groups was characterized as functionally active, the morphometry of the structural components of the thyroid gland showed a decrease in the thickness of the capsule and an increase in the size of follicles, thyrocytes and their nuclei.

The drug "Sedimin" had a positive effect on the formation of the parenchyma of the thyroid gland of piglets in all age periods. Histoarchitecture of the thyroid gland of piglets in a state of hypotrophy was characterized as hypofunctionalon the first and fifth days, but histophysiology was restored to thirty-day age.

\section{REFERENCES}

1. Demidovich AP. Hypotrophy in piglets in industrial complexes. Scientific notes of the educational institution Vitebsk State Academy of Veterinary Medicine. 2004; 40(1):47— 48.

2. Kurdeko AP, Demidovich AP. Gipotrofiya porosyat [Hypotrophy of pigs]. Vitebsk: Educational institution Vitebsk State Academy of Veterinary Medicine; 2005.

3. Kuznetsov AN, Glaz AV. Improvement of measures for prevention of oligofertility and hypotrophy of piglets in sows. Scientific notes of the educational institution Vitebsk State Academy of Veterinary Medicine. 2011; 47(2):75-77.

4. Petryankin FP, Petrova OY. Bolezni molodnyaka zhivotnykh: uchebnoe posobie [Diseases of young animals: Textbook]. 2nd ed. St. Petersburg: Lan' Publ.; 2014. 
5. Peterson CJ, Whitman V, Watson PA, Schuler HG, Morgan HE. Mechanisms of Differential Growth of the Heart Ventricles in Newborn Pigs. Circulation Research. 1989; 64(2):360-369.

6. Suleymanov SM, Parshin PA, Sapozhkova OA, Shaposhnikova YV, Pavlenko OB, Derezina TN. Structural organization of the endocrine glands in piglets is normal and with experimental rickets. Bulletin of the Voronezh State Agrarian University. 2016; (3):81-91.

7. Fedotov DN, Bobrik VM. Age and individual morphological features of the structure, arterial blood supply and innervation of the thyroid gland in pigs. Scientific notes of the educational institution Vitebsk State Academy of Veterinary Medicine. 2011; 47(1):308-313.

8. Fedotov DN, Luppova IM. Histoorganogenesis, adaptive transformations and the formation processes of the thyroid gland of piglets in the first month of postnatal ontogenesis. The Bulletin of Agrarian and Environmental University. 2008; 2(1):166-170.

9. Rassolov CN, Eranov AM. The endocrine activity of the thyroid gland of young pigs for fattening with the introduction of iodine and selenium preparations against the background of a probiotic. Achievements of Science and Technology of AIC. 2011; (12):63-64.

10. Paredes SP, Jansman AJM, Verstegen MWA, Awati A, Buist W, Den Hartog LA et al. Analysis of factors to predict piglet body weight at the end of the nursery phase. Journal of animal science. 2012; 90(9):3243-3251. Available from: doi: 10.2527/jas.2011-4574.

11. Arthur JR, Beckett GJ. Roles of Selenium in iodothyronine 5'-deiodinase and in thyroid hormone and iodine metabolism. In: Arthur JR, Beckett GJ. (eds.) Selenium in biology and human health. New York, NY: Springer; 1994. p. 93-115.

12. Dvořák M, Neumannová $M$, Bursa J. The relationship of serum thyroxine level to body mass of piglets during their postnatal development. Acta Veterinaria Brno. 1986; 55:11-21.

13. Parker RO, Williams PEV, Aherne FX, Young BA. Histological structure of the thyroid gland in the neonatal pig. Neonatology. 1980; 38(3-4):120-125.

\title{
INFORMATION ABOUT AUTHORS
}

Bilzhanova Gulnar Zhardymovna - PhD student of the Department of Morphology, Physiology and Pathology, Orenburg State Agrarian University, e-mail: bilzhanovagulnara@mail.ru

\section{For citation:}

Bilzhanova GZ. Histoarchitecture of the thyroid gland in piglets with hypotrophy and after the course of medical correction. RUDN Journal of Agronomy and Animal Industries, 2018, 14 (4), 294 302. doi: 10.22363/2312-797X-2018-13-4-294-302.

УДК: 636.4:611.4

DOI: 10.22363/2312-797X-2018-13-4-294-302

\section{ГИСТОАРХИТЕКТОНИКА ЩИТОВИДНОЙ ЖЕЛЕЗЫ ПОРОСЯТ ПРИ ГИПОТРОФИИ И НА ФОНЕ ЕЕ КОРРЕКЦИИ}

\author{
Г.Ж. Бильжанова \\ Оренбургский государственный аграрный университет \\ Оренбург, Российская Федерачия, 460014 \\ bilzhanovagulnara@mail.ru
}

Недостаточное поступление питательных веществ является условием, характеризующимся как потерей веса у животных, так и изменением морфофункциональных характеристик внутренних органов, особенно неполнотой структуры щитовидной железы, которая будет иметь прямое влияние на дальнейший рост и развитие животных. Поэтому целью исследования было установить закономерности гистоструктуры щитовидной железы у гипотрофических поросят и поросят после пренаталь- 
ной коррекции гипотрофии с учетом их возраста. Исследование проводилось на поросятах большой белой породы. Изучаемым материалом была щитовидная железа гипотрофических поросят и поросят после пренатальной коррекции с Седиминым в возрасте 1, 5, 15 и 30 дней. Основные методы исследования: гистологическая, морфометрическая и статистическая обработка данных.

По результатам исследования было установлено утолщение капсулы соединительной ткани щитовидной железы у новорожденных и пятидневных гипотрофических поросят в отношении пятнадцати и тридцатидневных. Средний диаметр фолликула находится на относительно равном уровне в течение всех периодов исследования, коллоид приобрел «пенистую» внешность на пятый и пятнадцатый день. Форма тироцитов и их ядер менялась с возрастом от сплющенного до кубического.

Функционально активна клеточная ткань щитовидной железы поросят после пренатальной коррекции недоедания. В первый и пятый дни капсула органа была разбавлена, и к концу исследования ее толщина заметно увеличилась. Диаметр фолликулов щитовидной железы снижался с неонатального периода до тридцатого дня. На протяжении всего эксперимента структура коллоида изменялась в просвете фолликула от однородной консистенции до «пенистого» к концу эксперимента. В начале эксперимента в паренхиме щитовидной железы наблюдались как сплющенные, так и кубические эпителиальные клетки, на тридцатый день они были стабильно кубическими. Ядры тироцитов в основном сферические и гипохромные.

В заключение следует отметить, что у гипотрофических поросят в неонатальном периоде и в пятидневный период наблюдалась неполнота структуры щитовидной железы, дальнейшая морфологическая реорганизация достигалась к тридцатому дню. Лекарство «Седимин» оказало положительное влияние на организм свиней, уменьшило степень развития недоедания и способствовало адекватному органо-гистогенезу, включая щитовидную железу.

Ключевые слова: поросята-гипотрофики, щитовидная железа, фолликул, тироцит, «Седимин»

\section{БИБЛИОГРАФИЧЕСКИЙ СПИСОК}

1. Демидович А.П. Гипотрофия у поросят в условиях промышленных комплексов // Ученые записки учреждения образования «Витебская государственная академия ветеринарной медицины». 2004. Т. 40. № 1. С. 47-48.

2. Курдеко А.П., Демидович А.П. Гипотрофия поросят. Витебск: УО ВГАВМ, 2005. 111 с.

3. Кузнецов Н.А., Глаз А.В. Совершенствование мероприятий по профилактике малоплодия и гипотрофии поросят у свиноматок // Ученые записки УО ВГАВМ. 2011. Т. 47. № 2. Ч. 2. С. $75-77$.

4. Петрянкин Ф.П., Петрова О.Ю. Болезни молодняка животных: учебное пособие. СПб.: Лань. 2014. 352 c.

5. Peterson C.J., Whitman V., Watson P.A., Schuler H.G., Morgan H.E. Mechanisms of differential growth of heart ventricles in newborn pigs // Circulation research. 1989. Vol. 64. № 2. P. $360-369$.

6. Сулейманов С.М., Паршин П.А., Сапожкова О.А., Шапошникова Ю.В., Павленко О.Б., Дерезина T.H. Структурная организация эндокринных желез у поросят в норме и при экспериментальном рахите // Вестник Воронежского государственного аграрного университета. 2016. № 3. С. 81-91.

7. Федотов Д.Н., Бобрик В.М. Возрастные и индивидуальные особенности морфологического строения, артериального кровоснабжения и иннервации щитовидной железы у свиней // Ученые записки УО ВГАВМ. 2011. № 1. С. 308-313.

8. Федотов Д.Н., Луппова И.М. Гистоорганогенез, адаптивные преобразования и формообразовательные процессы щитовидной железы поросят в первый месяц постнатального онтогенеза // Вісник Державной Аграэкологічного Университета. 2008. Т. 2. № 1. C. $166-170$.

9. Рассолов С.Н., Еранов А.М. Инкреторная активность щитовидной железы молодняка свиней на откорме при введении препаратов йода и селена на фоне пробиотика // Достижения науки и техники АПК. 2011. № 12. С. 63-64. 
10. Paredes S.P., Jansman A.J.M., Verstegen M.W.A., Awati A., Buist W., Den Hartog L.A., et al. Analysis of factors to predict piglet body weight at the end of the nursery phase // Journal of animal science. 2012. Vol. 90. № 9. P. 3243-3251. Available from: doi: 10.2527/jas.2011-4574.

11. Arthur J.R., Beckett G.J. Roles of Selenium in iodothyronine 5'-deiodinase and in thyroid hormone and iodine metabolism // Selenium in biology and human health. New York, NY: Springer, 1994. p. 93-115.

12. Dvoŕák M., Neumannová M., Bursa J. The relationship of serum thyroxine level to body mass of piglets during their postnatal development // Acta Veterinaria Brno. 1986. Vol. 55. P. $11-21$.

13. Parker R.O., Williams P.E.V., Aherne F.X., Young B.A. Histological structure of the thyroid gland in the neonatal pig // Neonatology. 1980. Vol. 38. P. 120-125.

\section{Для цитирования:}

Бильжанова Г.Ж. Гистоархитектоника щитовидной железы поросят при гипотрофии и на фоне ее коррекции // Вестник Российского университета дружбы народов. Серия: Агрономия и животноводство. 2018. Т. 13. № 4. С. 294-302. doi: 10.22363/2312-797X-2018-13-4-294-302. 